\title{
Upaya Meningkatkan Kemampuan Metakognisi Melalui Strategi Pembelajaran PAI Berbasis DDCT Pada Mahasiswa Sekolah Tinggi Agama Islam Ibnu Sina Batam
}

\author{
Nur'aini* \\ Sekolah Tinggi Agama Islam (STAI) Ibnu Sina-Batam, Indonesia \\ Jl. Teuku Umar, Lubuk Baja Kota, Kec. Lubuk Baja, Kota Batam, Kepulauan Riau 29444 \\ Email: nurainibatam20@gmail.com
}

\begin{abstract}
This study aims to improve students' metacognition abilities through PAIbased DDCT learning strategies. Through a quantitative approach, pre-test and post-test designs, it was concluded that the increase in students' metacognition abilities was generally in the "high" category, as many as 18 people or around $47.37 \%$, while students in the "medium" category were 11 people or around $28.94 \%$. While the group of students in the category of "low" as many as 9 people or about $26.68 \%$. Thus it can be said that the improvement of students' metacognition skills is very good. The data proves that the DDCT learning model can effectively improve students' metacognition abilities. Associated with the results of this study, the end of the study needs to be suggested, among others, it is necessary to improve the ability of metacognition through other subjects to ensure that every graduate has the ability to meet as part of the character of a scholar.
\end{abstract}

Keywords: Metacognition, Learning Strategies, Deep Dialog Critical Thinking

Abstrak: Penelitian ini bertujuan untuk meningkatkan kemampuan metakognisi mahasiswa melalui strategi pembelajaran PAI berbasis DDCT. Dengan demikian masalah utama yang akan dijawab dalam penelitian ini adalah bagaimana meningkatkan kemampuan metakognisi mahasiswa melalui strategi pembelajaran PAI berbasis DDCT pada mahasiswa Sekolah Tinggi Agama Islam Ibnu Sina-Batam. Melalui pendekatan kuantitatif, pretes dan postes desain diperoleh kesimpulan bahwa peningkatan kemampuan metakognisi mahasiswa secara umum berada pada kategori "tinggi", yaitu sebanyak 18 orang atau sekitar 47,37\%, adapaun mahasiswa dengan kategori "sedang" sebanyak 11 orang atau sekitar 28,94\%. Sedangkan kelompok mahasiswa dengan kategori "rendah" sebanyak 9 orang atau sekitar 26,68\%. Dengan demikian dapat dikatakan bahwa peningkatan kemampuan metakognisi mahasiswa sudah sangat baik. Data tersebut membuktikan bahwa model pembelajaran DDCT secara efektif mampu meningkatkan kemampuan metakognisi mahasiswa. Terkait dengan hasil penelitian ini, maka diakhir penelitian perlu disarankan antara lain perlu dilakukan peningkatan kemampuan metakognisi melalui mata kuliah yang lain guna memastikan bahwa setiap sarjana memiliki kemampuan metakognisi sebagai bagian dari karakter seorang sarjana.

Kata Kunci: Metakognisi, Strategi Pembelajaran, Deep Dialog Critical Thinking

Jurnal Pendidikan Agama Islam Al-Thariqah Vol. 5, No. 1, Januari - Juni 2020

Received: 28 February 2020; Accepted 05 June 2020; Published 16 June 2020

*Corresponding Author: nurainibatam20@gmail.com 


\section{PENDAHULUAN}

Pendidikan Agama Islam (PAI) merupakan jurusan dengan tujuan akhir adalah membentuk mahasiswa yang cerdas dan berkepribadian islami serta memiliki kemampuan berpikir dan menyadarai kemampuannya (kemampuan metakognisi). Dengan demikian, jelas bahwa pendidikan agama Islam merupakan salah satu program studi yang sangat urgent. Hal ini sebagaimana di sampaikan oleh (Budiman, 2017: 7) bahwa pendidikan agama Islam memiliki peran yang sangat penting dan strategis dalam setiap jenjang pendidikan. Dengan demikian jelas bahwa metakognisi merupakan bagian yang tidak terpisahkan dari tujuan pembelajaran PAI. Oleh karena itu perlu dilakukan sebuah penelitian yang fokus pada pengembangan atau peningkatan kemampuan metakognisi mahasiswa melalui model pembelajaran Deep Dialog Critical Thinking (DDCT).

Salah satu matakuliah yang wajib diikuti oleh mahasiswa di STAI Ibnu Sina Batam adalah Strategi Pembelajaran PAI. Matakuliah ini bertujuan untuk memberikan bekal kepada mahasiswa agar memiliki kemampuan dalam membelajarkan konten PAI kepada peserta didik. Selain itu, matakuliah ini juga bertujuan untuk memberikan kesadaran kepada mahasiswa bahwa Agama (Islam) merupakan sebuah nilai dan jalan hidup bagi setiap muslim, sehingga setiap muslim harus menjadikan Islam sebagai panduan dalam setiap proses berpikir dan bertindak. Oleh karena itu matakuliah ini merupakan bagian dari upaya membekali kemampuan pedagogi mahasiswa sekaligus konten (agama Islam), sehingga mereka mampu menguasai konten dengan baik dan mampu menyampaikan kepada peserta didik dengan efektif. Dengan demikian upaya meningkatkan kemampuan metakognisi mahasiswa merupakan salah satu keniscayaan. Salah satu upaya nyata yang dapat dilakukan adalah melalui matakuliah strategi pembelajaran PAI dengan model DDCT.

Berdasarkan uraian di atas, dapat dipahami bahwa penelitian ini bertujuan untuk meningkatkan kemampuan metakognisi mahasiswa melalui matakuliah strategi pembelajaran PAI. Dengan kata lain pertanyaan dari penelitian ini adalah bagaimana meningkatkan kemampuan metakognisi mahasiswa pada Sekolah Tinggi Agama Islam Ibnu Sina-Batam melalui matakuliah strategi pembelajaran PAI dengan model DDCT?

\section{KONSEP TEORI}

Dalam pendidikan metakognisi merupakan kemampuan yang sangat penting. Metakognisi terkait dengan kemampuan dalam mengedalikan atau mengontrol kemampuan kognitif. Secara singkat, metakognisi dapat disebut sebagai "berpikir tentang berpikir" (Moritz, 2007: 12). Romli, (2012: 1) menjelaskan bahwa metakognisi adalah suatu kesadaran mengenai segala sesuatu yang sudah diketahui dan apa yang belum diketahui. Sedangkan menurut Erwinsyah (2015: 29) metakognisi memberikan penekanan pada kesadaran berpikir seseorang tentang caranya berpikirnya sendiri.

Selain pendapat di atas metakognisi seperti disebutkan Agustina (2013: 1) yaitu berhubungan dengan berpikir tentang berpikir serta kemampuan seseorang dalam menggunakan strategistrategi yang diketahui untuk mencapai tujuan tertentu. Metakognisi juga dapat didefinisikan sebagai sebuah kesadaran untuk memperoleh pengetahuan secara mandiri serta menemukan solusi dari setiap permasalahan yang dihadapai (Anita dan Assagaf, 2019: 61).

Menurut definisi di atas, dapat dipahami bahwa metakognisi sangat penting untuk mengontrol seseorang dalam belajar dan berpikir. Daya kontrol 
terhadap kemampuan dalam belajar dan berpikir akan mendorong terciptanya proses belajar belajar dan hasil berpikir bisa lebih efektif dan efisien. Hal ini sejalan dengan pandangan Rhodes (2019: 7) bahwa metakognisi merupakan serangkaian proses yang digunakan oleh seorang individu guna memantau kemampuan dan cara berpikirnya serta prilaku dirinya sendiri. Dengan demikian kemampuan berpikir akan menjadikan seseorang memperoleh pengetahuan dan keterampilan secara lebih baik serta lebih mandiri. Hal ini dapat dipahami karena orang yang memiliki kemampuan metakognisi yang baik akan cenderung memiliki kemampuan berpikir, bersikap dan bertindak secara lebih terkontrol.

$$
\text { Menurut Lai (2011: 11) }
$$

pengetahuan metakognisi terdiri atas dua komponen utama yaitu pengetahuan dan regulasi. Pengetahuan metakognisi mencakup pengetahuan tentang dirinya sendiri yang terkait dengan faktor-faktor yang mempengaruhi kinerjanya, stretagi yang digunakan serta alasan menggunakan strategi tersebut. Adapun metakognisi regulasi mencakup perencanaan, kesadaran akan kinerja dan tanggungjawab, serta evaluasi terhadap kinerja pribadinya. Dengan demikian, jelas bahwa metakognisi sangat berperan terhadap kinerja tanggung jawab serta evaluasi diri.

Merujuk pada paparan di atas, dapat dipahami bahwa metakognisi terkait erat dengan kemampuan diri dalam mengatur dirinya sendiri, baik terkait dengan cara atau proses berpikir maupun terkait dnegan prilakunya. Dengan demikian metakognisi juga sering dikaitkan dengan self regulation. Dalam beberapa penelitian yang lain, metakognisi disebut sebagai self regulation (Zahary, 2015: 231), yaitu kemampuan untuk menjadi partisipan (belajar) yang aktif secara kognitif, motivasi, dan perilaku. Self regulation sangat berpengaruh positif terhadap prestasi akademik para pelajar. Hal ini juga sejalan dengan penelitian Ardhianingtyas dan Susilo (2017: 189), bahwa ada korelasi yang signifikan antara metakognisi dengan peningkatan prestasi akademik mahasiswa. Bahkan disebutkan bahwa kemampuan dalam mengatur diri sendiri (metakognisi) merupakan pusat atau inti dalam proses pembelajaran, pengambilan keputusan serta penyelesaian masalah dan manajemen sumberdaya dalam proses pendidikan (Cubukcu, 2009: 559).

Urgensi metakognisi juga terlihat dalam penelitian yang dilakukan oleh Erwinsyah (2015: 29), sehingga perlu dilakukan pengembangan sebuah bahan ajar berbasis metakognisi sebagai upaya optimalisasi proses berpikir. Hasil riset menunjukkan bahwa metakognisi memiliki hubungan yang kuat antara metakognisi dengan motivasi dan hasil belajar siswa (Saemah Rahman dan John Arul Philips, 2006: 21). Selain itu, metakognisi juga sangat berperan dalam meningkatkan kemampuan pemecahan masalah matematika (Anggo, 2011: 25). Riset ini juga diperkuat oleh Agustina (2013: 1), dan Labuhn, Zimmerman, dan Hasselhorn (2010: 173) bahwa setiap tingkatan kemampuan metakognisi siswa berpengaruh terhadap kemampuan menyelesaikan masalah dalam matematika serta dalam menilai dirinya sendiri. Hasil penelitian ini juga diperkuat oleh Anggo, Salam, Suhar, dan Santri, (2014: 26) bahwa penggunaan strategi metakognisi dapat meningkatkan hasil belajar matematika. Selain itu, metakognisi juga memiliki hubungan yang kuat dengan penguasaan konsepkonsep kimia mahasiswa (Danial, 2010a: 225).

Merujuk pada urgensi metakognisi sebagaimana telah dipaparkan di atas, saat ini penelitian terkait metakognisi secara masif terus dikembangkan oleh para ahli di beberapa negara (Brüchner, 2007: 7). Di Jerman misalnya, tes metakognisi dilakukan sebagai 
persyaratan masuk jurusan matematika (Artelt dan Neuenhaus, 2010: 162). Selain itu, penelitian tentang pengembangan instrument penilaian metakognisi juga terus dilakukan (Artelt, Weinert, dan Handel, 2013: 162).

Ada beberapa upaya yang dapat dilakukan guna meningkatkan kemampuan metakognisi para peserta didik. Beberapa upaya yang sudah berhasil dilakukan guna meningkatkan kemampuan metakognisi antara lain melalui penerapan model pembelajaran problem based learning (Danial, 2010b: 1). Melalui model pembelajaran tersebut dapat dilihat bahwa kemampuan metakognisi mahasiswa naik rata-rata sebesar 37,75\%. Dengan demikian dapat dipahami bahwa penggunaan modelmodel pembelajaran dapat meningkatkan kemampuan metakognisi mahasiswa. Selain itu, upaya peningkatan kemampuan metakognisi juga dapat dilakukan dengan pengembangan perangkat pembelajaran (Yuliani dan Indah, 2016: 314).

Salah satu model pembelajaran yang mengeksplorasi kemampuan berpikir adalah Deep Dialog Critical Thinking (DDCT). Proses pembelajaran dengan model DDCT berorientasi pada kegiatan diskusi (dialog) yang dilakukan secara serius dan mendalam dengan melibatkan kemampuan berpikir kritis (Arthana, 2010: 16). Karena melibatkan proses berpikir kritis, model pembelajaran DDCT sangat berperan dan terbukti mampu meningkatkan kemampuan berpikir kritis dan hasil belajar siswa sebagaimana penelitian sebelumnya (Aini, 2018: 60). Selain itu, A'yuni dan Budiwibowo (2014: 75) dalam penelitian juga menyebutkan bahwa model pembelajaran DDCT mampu meningkatkan hasil belajar siswa.

Merujuk pada penjelasan di atas, kemampuan berpikir dan prestasi belajar merupakan dampak positif dari implementasi model pembelajaran DDCT. Jika dikaitkan dengan metakognisi sebagai sebuah kesadaran akan kemampuan berpikir, bersikap dan bertindak, maka juga dapat dikatakan bahwa metakognisi sebagai sebuah hasil belajar. Makna ini dapat dipahami karena metakognisi merupakan suatu kesadaran, dan kesadaran merupakan suatu hasil dari proses belajar. Hal ini sebagaimana disebutkan oleh Hanafy (2014: 66) bahwa belajar merupakan suatu proses perubahan tingkah laku sebagai hasil interaksi antara individu dengan lingkungannya.

Dalam konteks keislaman, dialog atau komunikasi merupakan bagian yang tidak terpisahkan dalam proses dakwah. Hampir dalam setiap aktivitas dakwah selalu melibatkan proses komunikasi atau dialog. Di dalam Al-Qur'an banyak ditemukan proses dialog atau kominikasi lisan, baik itu menceritakan dialog antara Tuhan dengan para Rasul dan, dialog antara Tuhan dengan malaikat maupun dialog antara malaikat dengan rasul dan sebagainya. Hal ini, misalnya dapat ditemukan dalam Al-Qur'an surat AlBaqarah ayat 30, yakni dialog antara Tuhan dan malaikat (Kunci, 2015: 117). Dengan demikian hal ini juga menunjukkan bahwa DDCT sebagai model pembelajaran juga sejalan dengan nilai-nilai dalam Islam sebagai agama yang rahmatan lilalamin.

\section{METODE PENELITIAN}

Sebagaimana telah dijelaskan di atas bahwa, fokus dari penelitian ini adalah untuk meningkatkan kemampuan metakognisi mahasiswa melalui strategi pembelajaran PAI. Penelitian ini dilakukan dengan pendekatan kuantitatif dengan model kuasi eksperimen dengan menggunakan rancangan satu kelompok praperlakuan dan pascaperlakuan (Onegroup pretest -posttest design) sebagaiman yang dijelaskan oleh Hastjarjo (2019: 191). Dengan demikian, penelitian ini tidak melibatkan kelompok control. 
Data diperoleh dengan sebuah instrument untuk mengukur kemampuan metakognisi mahasiswa. Instrument yang digunakan dalam penelitian ini adalah menggunakan instrument Metacognitive Awareness Inventory yang telah dikembangkan sebelumnya oleh Schaw dan Dennison pada tahun 1994. Pada instrument tersebut indikator yang digunakan adalah: (1) pengetahuan tentang kognisi, (2) pengetahuan prosedural, (3) pengetahuan kondisional, serta (4) indikator regulasi (Ainun, 2019: 21).

Pengumpulan data dilakukan dengan model pretest dan postes. Pretes dilakukan sebelum pelaksanaan pembelajaran matakuliah strategi pembelajaran PAI, sedangkan postes dilakukan setelah proses pembelajaran selesai dilakukan. Penelitian ini melibatkan mahasiswa yang mengikuti mata kuliah Strategi pembelajaran Pendidikan Agama Islam, yakni sebanyak 38 orang. Dalam proses pelaksanaan pembelajaran digunakan model pembelajaran DDCT. Dengan pelaksanaan pembelajaran selama 16 kali pertemuan (satu semester), selanjutnya diakhir semester dilakukan postesguna melihat sejauh mana peningkatan kemampuan metakognisi mahasiswa tersebut.

Analisis data dilakukan dengan dua tahap. Tahap yang pertama dilakukan untuk melihat sejauhmana prosentase peningkatan kemampuan metakognisi setiap subyek. Untuk analisa data tahap ini dilakukan dengan rumus $\mathrm{N}$-gain yakni:

$$
N-\text { gain }=\frac{\text { Npost }- \text { Npre }}{\text { Nmak }- \text { Npre }} \times 100 \%
$$

Dimana:

1. N-gain adalah prosentase kenaikan kemampuan kognisi subyek.

2. Nos adalah Nilai postes yang diperoleh subyek.

3. NPre adalah Nilai prestes yang diperoleh subyek, dan

4. NMak adalah Nilai maksimum yang bias diperoleh subyek.
Tahap analisis selanjutnya, yaitu analisis tahap kedua yaitu untuk mengklasifikasi atau mengkategorikan peningkatan kemampuan metakognisi subyek. Adapun klasifikasi dilakukan dengan cara membandingkan antara skor yang diperoleh subyek dengan tabel ketentuan. Tabel ketentuan ini dapat dilihat sebagai berikut:

Tabel 1: Kategori Prosentase Kenaikan Kemampuan Metakognisi

\begin{tabular}{llll}
\hline No & $\begin{array}{l}\text { Rentang } \\
(\%)\end{array}$ & prosentase & Katogeri \\
\hline 1 & $71-100$ & Tinggi \\
2 & $31-70$ & Sedang \\
3 & $0-30$ & Rendah \\
\hline
\end{tabular}

\section{HASIL DAN PEMBAHAHASAN Hasil Penelitian}

Berdasarkan data hasil tes (pretes dan postes) yang selanjutnya dianalisis dengan rumus $\mathrm{N}$-gain dan dilakukan klasifikasi kategori, maka prosentase peningkatan kemampuan metakognisi mahasiswa dapat dilihat dalam tabel berikut ini:

Tabel 2: Prosentase Peningkan

Kemampuan Metakognisi Mahasiswa

\begin{tabular}{lllll}
\hline No & $\begin{array}{l}\text { Rentang } \\
\text { prosentase } \\
(\%)\end{array}$ & Jumlah & Prosentase & Katogeri \\
\hline 1 & $71-100$ & 18 & $47,37 \%$ & Tinggi \\
2 & $31-70$ & 11 & $28,94 \%$ & Sedang \\
3 & $0-30$ & 9 & $26,68 \%$ & Rendah \\
\hline & Total & 38 & $100 \%$ & \\
\hline
\end{tabular}

Berdasarkan table 2 di atas dapat dilihat bahwa peningkatan kemampuan metakognisi mahasiswa secara umum berada pada kategori "tinggi", yaitu sebanyak 18 orang atau sekitar 47,37\%. Kelompok selanjutnya beradasarkan pada table di atas terlihat bahwa kategori "sedang" sebanyak 11 orang atau sekitar 28,94\%. Adapun kelompok dengan kategori "rendah" sebanyak 9 orang atau sekitar 26,68\%. Dengan demikian jika dilihat secara umum bahwa peningkatan kemampuan metakognisi mahasiswa sudah sangat baik. Data tersebut membuktikan bahwa model pembelajaran DDCT secara efektif 
mampu meningkatkan kemampuan metakognisi mahasiswa.

\section{Pembahasan}

Sebagaimana telah dipaparkan pada table 2 di atas, bahwa secara umum mahasiswa peserta matakuliah stretagi pembelajaran PAI mengalami peningkatan kemampuan metakognisi secara baik. Hal ini membuktikan bahwa model pembelajaran model DDCT memberikan ruang yang cukup terhadap pengembangan kemampuan metakognisi mahasiswa. Hasil penelitian ini sejalan dengan penelitian sebelumnya yang menyatakan bahwa model pembelajaran DDCT mampu meningkatkan hasil belajar peserta didik (A'yuni dan Budiwibowo, 2014: 75). Adapun hasil belajar dalam konteks penelitian ini adalah metakogisi mahasiswa.

Adanya peningkatan kemampuan metakognisi mahasiswa sebagaimana paparan di atas, tidak terlepas dari karakter model DDCT itu sendiri. Menurut (Arthana, 2010: 16) bahwa DDCT merupakan model pembelajaran dengan menitik beratkan pada diskusi yang dilakukan secara mendalam (deep). Proses pembelajaran melalui kegiatan tersebut akan mendorong para mahasiswa mengeksplorasi kemampuan berpikir kritisnya secara optimal. Melalui proses tersebut maka hasil belajar para peserta didik akan meningkat. Tetu saja hasil belajar tersebut juga termasuk metakognisi.

Dilihat dari sudut pandang mata kuliah strategi pembelajaran PAI, mata kuliah ini merupakan salah satu mata kuliah wajib bagi seluruh calon guru PAI, sebagaimana dikatakan oleh (Mohammad Budiman, 2017: 7). Hal itu berarti dorongan atau motivasi mahasiswa dalam menguasai materi tersebut juga relative tinggi, sehingga turut serta dalam meningkatkan kualitas atau mutu proses pembelajaran. Mahasiswa yang serius tersebut pada giliranya akan mengikuti setiap tahap proses model DDCT yang diterapkan oleh dosen. Mutu atau kualitas proses pembelajaran tersebut yang selanjutnya akan mendorong mahasiswa serius dalam melaksanakan model pembelajaran DDCT, sehingga metakognisi sebagai target akhir bisa tercapai.

Merujuk pada urgensi metakognisi, sebagaimana telah dipaparkan oleh Brüchner, 2007: 7) bahwa kognisi merupakan kesadaran untuk berpikir dan belajar maka metakognisi sangat berpengaruh terhadap prestasi akademik pelajar. Dengan meningkatkan kemampuan metakognisi mahasiswa melalui strategi pembelajaran PAI tentu saja akan membawa dampak positif mahasiswa terhadap mata kuliah yang lainnya. Hal ini dapat dipahami karena peningkatakan kemampuan metakognisi yang berarti juga peningkatan kemampuan cara berpikir (berpikir tentang cara berpikir) sebagaimana disebutkan oleh Moritz (2007: 7). Kemampuan cara berpikir inilah yang selanjutnya akan meningkatkan kesadaran diri untuk berpikir, kemampuan mengontrol (kognitif) diri.

Merujuk pada hasil penelitian sebelumnya bahwa kemampuan metakognisi berpengaruh positif terhadap konsep diri (Ardhianingtyas dan Susilo, 2017: 189), maka peningkatan metakognisi juga berarti akan dapat meningkatkan rasa percaya diri, motivasi diri dan kesuksesan dalam belajar lainnya. Peningkatan kemampuan metakognisi mahasiswa setelah mengikuti perkuliahan PAI melalui model DDCT, juga dapat dipahami sebagai peningkatan kemampuan dirinya dalam mengelola, pikiran, motivasi belajar, kesadaran akan kerja dan tanggungjawab serta mengontrol prilaku dirinya sendiri.

Kemampuan dan mengontrol pikiran, prilaku, bersikap dan bertindak merupakan salah satu bentuk kecerdasan emosi. Hal ini sebagaimana dikatakan 
oleh Utama (2018: 7) bahwa kecerdasan emosi merupakan kemampuan seseorang dalam mengelola segara dorongan perasaan yang ada pada dirinya. Dorongan perasaan yang dimaksudkan dalam konteks ini bisa saja berupa dorongan untuk berpikir, bersikap dan bertindak sebagai hasil dari adanya kesadaran diri.

Tumbuhkembangnya kecerdasan emosi serta kesadaran dalam berpikir, bersikap dan bertindak ini juga akan menjadi modal penting ketika para mahasiswa kelak menjadi seorang guru PAI. Sebagaimana diketahui bahwa ada empat kompetensi guru, yaitu: kompetensi profesional (kemampuan akan konten), kompetensi pedagogik (kemampuan mengelola peserta didik), kompetensi sosial dan kompetensi kepribadian. Keempat kompetensi ini merupakan bagian dari metakognisi. Hal ini dapat dipahami, keempat kompetensi tersebut akan tumbuh dan berkembang karena adanya kesadaran dari para pelakunya. Dengan demikian dapat dikatakan bahwa metakognisi merupakan kunci keberhasilan seorang guru.

Selain dituntut menjadi guru yang berkompeten, mahasiswa calon guru PAI juga dituntut untuk mampu mengambangkan dan menerapkan nilainilai keislaman sebagai bagian kehidupannya. Oleh karena itu guru PAI juga harus mampu mendakwahkan nilainilai keislaman ditengah-tengah masyarakat. Kesuksesan dan kegagalan dari tugas ini sangat dipengaruhi oleh adanya kesadaran akan kemampuan dan tanggung jawabnya sebagai seorang guru PAI. Hal ini juga berarti metakognisi sangat penting, dan DDCT sebagai model pembelajaran juga turut berperan.

Merujuk pada paparan di atas, jelas bahwa metakognisi merupakan salah satu hasil belajar yang sangat penting, tidak hanya untuk dirinya akan tetapi juga berdampak positif bagi lingkungannya. DDCT sebagai model pembelajaran telah secara nyata mampu meningkatkan metakognisi mahasiswa sampai pada level peningkatan yang sangat baik. Dengan demikian jelas, bahwa model pembelajaran DDCT tidak hanya mampu meningkatkan kemampuan metakognisi mahasiswa, akan tetapi secara tidak langsung juga akan meningkatkan prestasi akademik dan kualitas kehidupan mereka.

\section{PENUTUP}

Merujuk pada data dan pembahasan yang telah dilakukan, maka diakhir penelitian ini dapat disimpulkan bahwa peningkatan kemampuan metakognisi mahasiswa secara umum berada pada kategori "tinggi", yaitu sebanyak 18 orang atau sekitar 47,37\%. Kelompok selanjutnya berada pada kategori "sedang" sebanyak 11 orang atau sekitar 28,94\%. Adapun kelompok dengan kategori "rendah" sebanyak 9 orang atau sekitar 26,68\%. Dengan demikian jika dilihat secara umum bahwa peningkatan kemampuan metakognisi mahasiswa sudah sangat baik. Data tersebut membuktikan bahwa model pembelajaran DDCT secara efektif mampu meningkatkan metakognisi mahasiswa.

Terkait dengan hasil penelitian ini, maka disarankan perlunya peningkatan kemampuan metakognisi melalui mata kuliah yang lain guna memastika bahawa setiap sarjana memiliki kemampuan metakgnisi sebagai bagian dari karakter seorang sarjana. Selain itu, perlu juga dilakukan pengembangan bahan ajar dan perangkat pembelajaran berbasis metakognisi guna membiasakan setiap mahasiswa memiliki kemampuan metakognisi yang baik.[]

\section{DAFTAR RUJUKAN}

A'yuni, A. Q., \& Budiwibowo, S. "Pengaruh Metode Diskusi Dengan Model Pembelajaran DD-CT (Deep Dialogue-Critical Thinking) Dengan 
Pemberian Penguatan Terhadap Prestasi Belajar Akuntansi Pada Siswa Kelas Xi Akuntansi Smkn 1 Geger Madiun". Assets: Jurnal Akuntansi Dan Pendidikan 3.2 (2014): 75-84.

Agustina, Mahromah, L. "Identifikasi Tingkat Metakognisi Siswa Dalam Memecahkan Masalah Matematika Berdasarkan Perbedaan Skor Matematika. Mathedunesa 2.1. (2013): 1-8.

Aini, Q. "Pengaruh Pembelajaran Inovatif Berbasis Deep Dialog/Critical Thinking (DD/CT) Terhadap Kemampuan Berpikir Kritis Dan Hasil Belajar Siswa Pada Matapelajaran Ekonomi Di MA NW Suralaga". JPEK Uurnal Pendidikan Ekonomi dan Kewirausahaan) 2.1. (2018): 60-71.

Ainun, Fauziah, H., Putri Setyowati, A., Dewantari, R., Dwi Wulandari, A., \& Adi Prayitno, B. "Profil Kesadaran Metakognisi Siswa di salah satu SMA Swasta di Sragen". Biosfer: Jurnal Biologi Dan Pendidikan Biologi 3. 2 (2019): 21-19.

Anggo, M. "Pelibatan Metakognisi dalam Pemecahan Masalah Matematika". Edumatica 1.1. (2011): 25-32.

Anggo, M., Salam, M., Suhar, dan Santri, Y. "Strategi Metakognisi untuk Meningkatkan Hasil Belajar Matematika Siswa". Jurnal Pendidikan Matematika 5.2. (2014): 84-91.

Anita, A.-, \& Assagaf, S. L. H. "Analisis Kemampuan Metakognisi Mahasiswa Calon Guru". VOX Edukasi: Jurnal Ilmiah Ilmu Pendidikan 10.1. (2019): 61-65.

Ardhianingtyas, N., dan Susilo, H. M. "Hubungan Konsep Diri dan Metakognitif dengan Prestasi Belajar Di AKBID Ummi Khasanah". Prosiding: Seminar Nasional Dan Presentasi Hasil - Hasil Penelitian
Pengabdian Masyarakat (2017): 189-198.

Artelt, C., dan Neuenhaus, N. "Metakognition und Leistung. Schulische Lerngelegenheiten Und Kompetenzentwicklung". Jerman: Festschrift Für Jürgen Baumert, 2010.

Artelt, C., Weinert, S., dan Händel, M. "Assessing metacognitive knowledge: Development and evaluation of a test instrument Erfassung metakognitiven Wissens: Entwicklung und Evaluation eines Testinstruments usammenfassung". Journal for Educational Research Online Journal Für Bildungsforschung Online 5.2 . (2013): 162-188.

Arthana, K. P. "Pembelajaran Inovatif Berbasis Deep Dialogue/Critical Thinking". Jurnal Teknologi Pendidikan 10.1 (2010): 16-21.

Brüchner, K. "Metakognition und Lernen in Chemie Studien zur Domänengeneralität versus Domänenspezifität und Förderung der Metakognition beim Lernen in Chemie". Philosophische Fakultät. 2007.

Cubukcu, F. "Metacognition in the classroom". Procedia - Social and Behavioral Sciences 1 (2009): 559563.

Danial, M. "Kesadaran Metakognisi, Keterampilan Metakognisi dan Penguasaan Konsep Kimia Dasar". Jurnal Ilmu Pendidikan 17.3 (2010): 225-229.

Danial, M. "Pengaruh Strategi PBL Terhadap Keterampilan Metakognisi dan Respon Mahasiswa". Chemica 11.2 (2010b): 1-10.

Erwinsyah, E. "Pengembangan Modul Fisika Materi Momentum dan Impuls Berbasis Metakognisi untuk Siswa Kelas XI SMA PGRI Tanjung Pandan Belitung". Jurnal Riset Dan 
Kajian Pendidikan Fisika 2.2 (2015): 29-34.

Hanafy, M. "Konsep Belajar Dan Pembelajaran". Lentera Pendidikan : Jurnal Ilmu Tarbiyah Dan Keguruan. 17.1 (2014): 66-79.

Hastjarjo, T. D. (2019). Rancangan Eksperimen-Kuasi. Buletin Psikologi. 27.2. (2019): 187-203.

Kunci, K. "Konsep Komunikasi Dakwah Persuasif Dalam Perspektif AlQur'an". At-Tabsyir: Jurnal Komunikasi Penyiaran Islam. 2.2. (2014): 117-136.

Labuhn, A. S., Zimmerman, B. J., dan Hasselhorn, M. "Enhancing students' self-regulation and mathematics performance: The influence of feedback and self-evaluative standards". Metacognition and Learning. 5 (2010): 173-194.

Lai, E. R. "Metacognition: A Literature Review Research Report". Research Reports. 2011.

Mochammad, Arif. "Pendidikan Agama Islam". Banjarbaru: Grafika Wangi Kalimantan, 2017.

Moritz, S. "Metakognition - Psychologie. In Neuropsychologie der Schizophrenie", 2017.

Rhodes, M. "Metacognition. Teaching of Psychology." 2019.

Romli, M. "Strategi Membangun Metakognisi Siswa SMA dalam Pemecahan Masalah Matematika". Aksioma. 1.2 (2012): 1-16.

Saemah, R., John Arul Philips. "Hubungan antara kesedaran metakognisi, motivasi dan pencapaian akademik pelajar universiti" 1 (2006): 21-39.

Utama, F. "ESQ Way 165: Alternatif Metode Pengembangan Kecerdasan Emosi dan Spiritual Anak". Journal of Early Childhood Care and Education. 1.1 (2018): 7-12.

Yuliani dan Indah, N. K. "Validitas dan Efektivitas Perangkat Pembelajaran Berorientasi Strategi Belajar Metakognisi KWL (Know-Want-
Learned) Pada Submateri Katabolisme Karbohidrat". BioEdu. 5.3. (2016): 314-320.

Zahary, M. "Meningkatkan Prestasi Belajar Matematika Siswa Melalui Strategi Self Regulated Learning". Seminar Nasional Matematika Dan Pendidikan Matematika Uny. M.35. (2015): 231-236.

Katsir, I. Tafsir Ibnu Katsir. Jakarta: Pustaka Imam Syafii, 2013.

Nudin. Urgensi Penanaman Sifat Amanah pada Peserta Didik di Madrasah Aliyah Swasta Wadiabero Kecamatan Gu Kabupaten Buton Tengah. Makassar: UIN Alauddin Makassar, 2018.

Pulungan, S. Wawasan Tentang Amanah dalam Al-Quran. Jakarta: UIN Syarif Hidayatullah, 2006.

Purwanto, M. N. Psikologi Pendidikan. Bandung: PT. Remaja Rosdakarya, 2006.

Sanjaya, W. Strategi Pembelajaran Berorientasi Standar Proses Pendidikan. Jakarta: Kencana, 2009.

Sugiyono. Kamus Bahasa Indonesia. Jakarta: Pusat Bahasa, 2008. 